\title{
The Growth Character and Results of Hybrid Corn Parents From Three-Way Crossing to Produce Hybrid Corn Seed Variety of Bima URI 20
}

\author{
Sodiq Jauhari ${ }^{1, *}$, R Heru Praptana ${ }^{1}$, Samijan ${ }^{1}$ and Renie Oelviani ${ }^{1}$ \\ ${ }^{1}$ Assessment Institute for Agriculture Technology of Central Java
}

\begin{abstract}
The character of growth and production of hybrid maize seeds in Bima URI 20 used a three-way cross. The female elders of Bima 4 variety and male elders (G180 / Mr14 x Nei 9008P). The research objective was to see the relationship between growth and three-bonded mother trees in the production of Bima 20 URI hybrid maize seeds. The research was conducted in Kendal Regency with an area of 2 hectares in MK-1 2019 through the OFCOR (On-Farm Client-Oriented Research) approach. This research uses descriptive analysis and the relationship between variables. The results showed that genetic and environmental factors influenced the growth of parent seeds. Rise of male elders $96.5 \%$, female elders $98.6 \%$, Tall plants $208.5 \mathrm{~cm}$, male elders $148.4 \mathrm{~cm}$, ear height $74.1 \mathrm{~cm}$, male elders $57.9 \mathrm{~cm}$, age the female flowers 50.35 , and male flowers 47.8. The results of the assessment test for the parameters of ear weight assessment, seed weight per ear, and 1000 dry seed weight resulted in a value of $0.8-0.9$ that indicated that the characters had a strong effect on plant productivity and growth.
\end{abstract}

\section{Introduction}

The quality of hybrid corn seeds can increase maize production. Hybrid maize varieties were proven to be able to increase production by $15 \%$ compared to the seed corn composite [1]. In the last few decades, the average yield of hybrid maize seeds is still relatively low, equal when compared to hybrid seeds, hybrid varieties without seeds still occupy the highest position in terms of production. However, with the relatively low yield of hybrid maize seeds, the price of F1 hybrid maize seeds is expensive. For this reason, it is necessary to make efforts to increase the growth of female broodstock so that they can meet the high productivity and quality of hybrid maize seeds.

${ }^{*}$ Corresponding Author: so.jauhari@yahoo.com 
One of the obstacles in the production of single-cross F1 hybrid seeds is the low seed yield (only 1.0-1.5 $\mathrm{t} / \mathrm{ha}$ ) compared to the production of F1-cross hybrid seeds that can reach 4-5 $\mathrm{t} / \mathrm{ha}$, depending on the type of seed class and varieties. Among other things, the price of single F1 hybrid seeds is quite costly, reaching IDR 100,000/ $\mathrm{kg}$. In its development, the planting of hybrid maize in Indonesia is quite rapid, reaching $56 \%$ of the total harvest area for maize [2].

That shows that farmers believe hybrid maize can increase production. Farmers try to get the hybrid seeds they want, even though they sometimes complain about the high price of the suds. This condition makes farmers want to be able to produce hybrid seeds himself, by finding out how to makeover hybrid corn seeds.

The hybrid maize currently being developed is mostly single cross hybrid, and the seed yield of F1 hybrid crosses is generally low. Many factors influenced the level corp of single-cross hybrid F1 seeds, including (1) synchronization of flowering between female and male plants when seed production was not suitable; (2) the composition of male and female plants is not precise, (3) pollen production is lowest, (4) ear hair is a limited fertility period (quickly withers), (5) cobs are deceased, and (6) minimum yield, (7) the yield potential of the female parent used is low [3]. In contrast to the three-way cross hybrids, the female parent used is a single $\mathrm{F} 1$ cross so that seed productivity can reach $5 \mathrm{t} / \mathrm{ha}$. The potential yield of a three-lane cross itself is the same as a single cross. Thus, the development of a three-way hybrid corn seed system requires an understanding of the character and potential of the prospective three-way hybrid system. The research objective was to determine the relationship between performance and growth and production characters of Bima 20 URI hybrid maize with three-way crossing parents.

\section{Research Methods}

The research was conducted on a farmer's land in Wirosari Village, Patean District, The province of Kendal that an area of 2 ha. Planting uses a spacing of 50 x $40 \mathrm{~cm}$, two plants/holes with an integrated crop management approach system. The female parent plant is a single cross hybrid Origin of crossing G180// Mr14 as a female parent with pure strain Nei9008P as male parent (G180 / Mr14 x Nei9008P). The composition of the male and female parents is 1: 4 (Figure 1). Fertilizer is given at a dose of $350 \mathrm{~kg}$ Ponska / ha +250 $\mathrm{kg}$ Urea / ha. Fertilizer is assumption twice, which is 7-10 days after planting, and when 3035 days after planting.

The amount of fertilizer applied at 7-10 days after planting is $300 \mathrm{~kg}$ Ponska / ha, at 3035 HST $200 \mathrm{~kg}$ urea $+50 \mathrm{~kg}$ Ponska/ ha, and at 45 days after planting $50 \mathrm{~kg}$ urea/ha. Organic fertilizer is given $2 \mathrm{t} /$ ha given at planting. The cultivation activities are finish by detachment and roguing activities. Data collected included seed growth, plant height, cob height, and yield. To find out the value of an independent variable, either one or more variables (independent) without making comparisons or linking with other variables in a descriptive analysis.

The data is presented using mean values that are displayed in the form of graphic images. To find out the linear relationship between variables using the analysis Correlation value is calculated using the formula:

$$
r=\sum X Y-\sum X J Y Y \sqrt{ }\left(x 2-\left(\sum x\right) 2 n\right)\left(Y 2--\left(\sum Y\right) 2 n\right) .
$$




\section{Results and Discussion}

The results of field observations showed that the performance of hybrid maize plants was quite good (98.6\%), while for male elders $96.5 \%$ was supported by optimal environmental performance. The factors that influence the growth of these seeds are soil, water availability, and other biotic factors. The ability to plant quite good maize is also causing by seed genetics and seed viability and vigor that are still very good [4]. Several factors that affect the rate of seed decline include the type of seed, weight, and part of the injured seeded, humidity, and environmental temperature in the field. Seed quality is one of the factors that influence and determine the yield

Optimal plant growth is an indication of good seed quality. The high rate of seed growth is due to the proven selection of seeds and germination capacity. Then with a sufficient harvest age, physiologically ripe seeds will respond well to the assimilation process, and seed viability is formed and well developed as well. A plant will show maturity if the total energy used has reached a certain level (growing days) and a certain level that varies from plant to plant due to genetic factors.

\section{Components of the growth of dry maize hybrid parent plants Th. 2019}

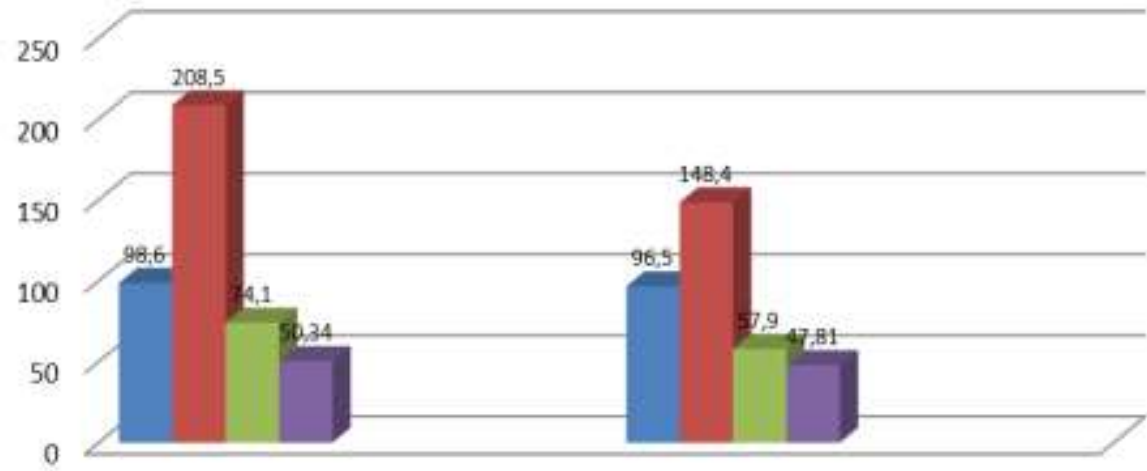

Female parent

Average growth rate $(\%)$

COB Height $(\mathrm{cm})$

Male parent

Average plant height

(cm)

Fig. 1. Components of the growth of the dry hybrid maize parent plant in 2019

Quality seeds are one of the requirements for the success of plant cultivation [5]. The production potential of a corn variety will only be seen if the physiological quality of the seeds is also held in addition to physical quality. Seeded with high physiological attributes are more responsive to fertilization [6]. This difference is also keep-up by components of plant growth, ear, and flowering age components. Genetic factors and the growth environment will give the appearance of genotypic and phenotypic diversity in the plant growth phase. The height of the male parent plant has an average value of $148.4 \mathrm{~cm}$ lower than the mean upper of the female parent plant of $205.8 \mathrm{~cm}$.

Genetic factors are more dominant in causing the performance of parent seed growth than environmental factors. Plant genotypes show differences in plant growth [7]. This opinion is in line with the results of field observations that show that male parent plants (NEI 9008) show lower and more uniform plant height growth compared to female parents 
(Bima 4). In addition to genetic factors, the interaction with the growing environment in each parent has a different response growth [8].

The composition of the spacing applied is $50 \mathrm{~cm} \times 40 \mathrm{~cm}$. This condition causes competition for light response in maize plants. The density population will cause elongation. Corn with an average height of $208.5 \mathrm{~cm}$ female and $148.4 \mathrm{~cm}$ male parent. The development of corn cropping can be seen from the lengthening of the stem segments, and the smaller the stems that cause an increase in plant height and can increase the level of plant vulnerability. Genotype factors also significantly influence the appearance and growth character of male and female parent plants.

Figure 1 illustrates the components of growth and production in plants. The average agronomic growth of ear height in different plants for male parents, the average value is $57.9 \mathrm{~cm}$, while female parents give a mean grade for ear height $74.1 \mathrm{~cm}$. the genotype allows for this difference. Also, ear height in plants good affects breeders' preferences. Farmers prefer the location of the cob that is not too high because this makes harvesting easier [6]. Like-minded, the position of the cob that is ripe up or perpendicular to the angle down. The F1 hybrid variety (Bima 20 URI) or male parent (NEI.9008) produces an average downward slope. One of the advantages of the downward sloping or perpendicular cob is that water does not enter easily. Makes it esker to dry in the tree, spreads faster, and is easy to pick.

The appearance of $50 \%$ of male flowers shows a difference that the parent plant being dependable. The time variable of $50 \%$ of female flowers showed that the difference in genotype caused a $50 \%$ difference in bloom time between female flowers and male flowers (Graph 1). 50\% flowering age has a positive correlation with the age of the plant or the harvest period, meaning that the varieties with a flowering age of $50 \%$ are shorter, the ripe age of the line/varieties is also shorter or early ripening [9]. Each genotype has a different vegetative growth time so that the flowering time is also unusual. From several genotypes tested, it was seen that male parents flowered faster at 47.81 days compared to females at 50.34 days (Graph 1). That male flowers appear 1-3 days before the appearance of female flowers. This condition enables synchronization in the process of pollination and fertilization so that it has the potential to produce maximum production.

Table 1. Average yield components and production of Bima 20 hybrid corn seeds URI dry season 2019in Wirosari Village, Patean District, Kendal Regency2020

\begin{tabular}{|c|l|l|c|c|c|c|c|}
\hline Repeat & $\begin{array}{l}\text { Cob } \\
\text { Weight } \\
(\mathbf{g})\end{array}$ & $\begin{array}{l}\text { Weight } \\
\text { of Waste } \\
\text { / plant } \\
\text { (g) }\end{array}$ & $\begin{array}{l}\text { Weight } \\
\text { of 1000 } \\
\text { Seeds (g) }\end{array}$ & $\begin{array}{l}\text { Average } \\
\text { weight. } \\
\text { Seeds per } \\
\text { cob (g) }\end{array}$ & $\begin{array}{l}\text { Water } \\
\text { Content } \\
(\%)\end{array}$ & $\begin{array}{l}\text { Yield } \\
(\%)\end{array}$ & $\begin{array}{l}\text { Seed } \\
\text { yield } \\
\text { (kg / } \\
\text { ha }\end{array}$ \\
\hline 1 & 430 & 120 & 1000 & 200 & 29.8 & 69,9 & 2,33 \\
\hline 2 & 380 & 105 & 710 & 142 & 27.3 & 65,1 & 1,99 \\
\hline 3 & 420 & 100 & 950 & 190 & 27.5 & 69,3 & 2,24 \\
\hline 4 & 410 & 140 & 945 & 189 & 29.9 & 69,7 & 2,23 \\
\hline Average & 410 & 116,25 & 901,3 & 180,25 & 28,6 & 68,5 & 2,21 \\
\hline
\end{tabular}

Source: primary data 2019

The results of the Bima 20 URI hybrid maize seed production activity involving four cooperative farmers showed an average seed production of $2.21 \mathrm{t} /$ ha of a dry shell with a moisture content of $10.6 \%$. The lowest seed yield was $1.99 \mathrm{t} / \mathrm{ha}$, and the highest yield was $2.33 \mathrm{t} / \mathrm{ha}$. This difference in results is due to the cultivation system that is not optimal. The main growth environment is the difference in spacing that causes the number of plant populations to differ in increasing the population per unit area. Thus, the use of high-quality seeds with the ability to grow above $95 \%$ of the captive farmers of Central Java AIAT is a separate consideration in increasing the average seed yield. 
The first fertilization is complete at the age of 10-15 days after planting with Urea 150 $\mathrm{kg}$, SP36 $100 \mathrm{~kg}$, and Phonska $150 \mathrm{~kg} / \mathrm{ha}$, and the second fertilization at the age of 30-35 HST with Urea $50 \mathrm{~kg} / \mathrm{ha}$ fertilizer. It turned out that the yield of 20 URI hybrid corn seedlings was still below its true potential, namely $5-7 \mathrm{t} /$ ha. That is partly because the cultivation technique is not optimal, not all farmers follow the recommendation of cultivation technology because of the limited will and ability who are already usual to farming experience. From field observations that are not complete simultaneously, this gap time will have an impact on the quality of pollination. Display that male plants do not perform perfect cross-pollination, so that the cob is not full, only $51 \%$ [10]. The position of the spacing and the comparison of the location of the male and female parents is quite critical to note.

The spacing of the nurseries at the activity location is applied $50 \mathrm{~cm} \mathrm{x} 40 \mathrm{~cm}$ with two seeds per hole. It is designed that the density of the plant canopy position is sufficient to determine the quality of production and survival of pollen. The closer the planting distance, the lower the quality of the pollination power in this condition due to the accumulation of leaves between plants which has an impact on the quality and quantity of seed prospective seeds. Synchronization of panicle formation in male and female plants ensures optimal fertility [10].

A condition will good affect the formation of cob or production. That one of the limiting factors in hybrid corn seed production is time synchronization and perfection in pollination. Cleanliness of male flowers in female parent plants and treatment of disposal of intersection types at dominant plant locations. Also good determines the quality and yield of prospective seed production. Environmental stresses such as water stress (strengths and weaknesses), nutrient stress (deficiency and poisoning), exposure to herbicides or pest and disease attacks will cause plants to grow irregularly, or not by plant morphology. It is also argued that the production of a single cross-hybrid corn seed experiencing water stress can reduce seed yield. The same thing happened with three-lane cross hybrid corn.

Achievement of seed production results is not optimal to get an average yield of $2.21 \mathrm{t} /$ ha. The results of the identification of the assessment location showed the lack of quality of the support growing environment canful slow the growth of cob and seed formation. The cause is too lush due to the accumulation of leaves between plants that have pollination by tepung sari that brings fort imperfectly results in a decrease in seed yield in hybrid F1 production [11]. Research in Takalar (Sul-Cell) shows the results of F1 seeds from STJ-01 at optimal conditions that can reach $4 \mathrm{t} /$ ha [12].

The observations showed that the female parent plant was planted direct side by side with males, get perfect pollination so that the cob is full til female plants that are not irectlydjacent, or canopy leaves that are too lush will have an impact with less than optimal pollination quality.

Table 2. Correlation coefficients of yield components and yield of hybrid corn seeds URI20 dryseason of 2019

\begin{tabular}{|l|l|l|c|c|c|c|}
\hline & Production & $\begin{array}{c}\text { Corn cobs } \\
\text { weight }\end{array}$ & $\begin{array}{c}\text { Weight } \\
\mathbf{1 0 0 0} \\
\text { seeds }\end{array}$ & $\begin{array}{c}\text { Seed weight } \\
\text { per corncob }\end{array}$ & $\begin{array}{c}\text { Plant } \\
\text { height }\end{array}$ & $\begin{array}{c}\text { corncob } \\
\text { position }\end{array}$ \\
\hline Production & 1 & $0.92^{* *}$ & $0.94^{* *}$ & $0.88^{*}$ & $-0,04^{\text {tn }}$ & $-0,74^{\text {tn }}$ \\
\hline Corn cobs weight & & 1 & $0.99^{* *}$ & $0.97^{* *}$ & $-0,15^{\text {tn }}$ & $-0,46^{\text {tn }}$ \\
\hline $\begin{array}{l}\text { Weight of 1000 } \\
\text { seed }\end{array}$ & & 1 & $0,95^{* *}$ & $-0,15^{\text {tn }}$ & $-0,38^{\text {tn }}$ \\
\hline \multicolumn{2}{|l|}{ Seed weight per corncob } & & & 1 & $-0,39^{\text {tn }}$ & $-0,61^{\text {tn }}$ \\
\hline Plant height & & & & & 1 & $0,366^{\text {tn }}$ \\
\hline COB position & & & & & & 1 \\
\hline
\end{tabular}

Note: $* *$ significantly different at the $5 \%$ correlation test * significantly lower atlevel $5 \%$

$\mathrm{And}^{\mathrm{t}}$ not significantly different at level 5\% 
The results of the analysis of the correlation coefficient on the achievement of dry shelled corn results showed a very significant positive correlation with the weight of 1000 seeds, the burden of the cob until the burthen of the cranked seeded was significantly positive. This yield component shows the character relationship that has a close enough direct influence value between the yield of 1000 seeds, the weight of the cobs, and the burden of the seeded in the cobs. This conditions mean that these three characters have an actual close relationship to the production of dry shelled seeds. While the results of the correlation analysis of plant height parameters and the position of the cobs did not affect the results of the production of corn dried shelled yields. It is fishy that this parameter is more act upon by the interaction of genetic factors with a suitable growing environment.

\section{Conclusion}

1. The quality of the parent seed resulting from a three-lane cross and the growing environment produces different growth power, namely $96.5 \%$ male parent and $98.6 \%$ female parent. The maximum plant height for female parents is $208.5 \mathrm{~cm}$ and for female parents is $148.4 \mathrm{~cm}$. The plant height of the female parent is $194 \mathrm{~cm}$ and 141 $\mathrm{cm}$. The burn of the ear for male parents was $59.2 \mathrm{~cm}$ and for female parents was 73.8 $\mathrm{cm}$.

2. The primary corn seed produced by crossing three lines (STJ) with a spacing of $50 \mathrm{~cm}$ $\mathrm{x} 40 \mathrm{~cm}$ gave a miserable density of pollination quality with a yield of $2.21 \mathrm{t} / \mathrm{ha}$.

3. Growth traits and yield components have a positive correlation with yield, except for the growth components of plant height and position of corn cobs, which give a negative correlation value to yield.

Acknowledgment. The acknowledgment to the Head of the Assessment Institute for Agricultural Technology Central Java, who provided research and assessment facilities, as well as related agencies and cooperating farmers as partners in carrying out research and assessment activities so that the activities ran bland as expected. Thanks also go to Prof. Agus Hermawan, Ph.D., and Ir. Budi Utomo, MP as the assessment member and supervisor of writing preparation.

\section{Reference}

1. F. Gao, M. Anderson, C. Daughtry, A. Karnieli, D. Hively, and W. Kustas, Remote Sensing of Environment 242, (2020).

2. BPS, Luas Panen Jagung 2014 - 2018 (Jakarta, 2019).

3. H. U. Jan, M. Guan, M. Yao, W. Liu, D. Wei, A. Abbadi, M. Zheng, X. He, H. Chen, C. Guan, R. A. Nichols, R. J. Snowdon, W. Hua, and L. Qian, Plant Science 283, 157 (2019).

4. P. Boddupalli, L. M. Suresh, F. Mwatuni, Y. Beyene, D. Makumbi, M. Gowda, M. Olsen, D. Hodson, M. Worku, M. Mezzalama, T. Molnar, K. S. Dhugga, A. Wangai, L. Gichuru, S. Angwenyi, Y. Alemayehu, J. Grønbech-Hansen, and P. Lassen, Virus Research 282, (2020).

5. R. Oelviani and J. Sodiq, in Inovasi Teknologi Spesifik Lokasi Untuk Peningkatan Produksi Pajale (2018), pp. 247-269.

6. S. Saenong, Teknologi Benih Jagung (Maros, 2018).

7. E. Mrema, H. Shimelis, M. Laing, and L. Mwadzingeni, Journal of Integrative Agriculture 17, 1585 (2018). 
8. Y. Xu, X. Liu, J. Fu, H. Wang, J. Wang, C. Huang, B. M. Prasanna, M. S. Olsen, G. Wang, and A. Zhang, Plant Communications 1, 100005 (2020).

9. H. yong LI and L. Thomas, Journal of Integrative Agriculture 17, 965 (2018).

10. M. Yasin, in Seminar Nasional Serealia (Balit Serealia Badan Litbang Pertanian, Maros, 2013), pp. 155-161.

11. A. Ruiz-Navarro, V. Fernández, J. Abadía, A. Abadía, J. I. Querejeta, J. Albaladejo, and G. G. Barberá, Environmental and Experimental Botany 167, (2019).

12. M. K. Kansiime and A. Mastenbroek, Journal of Rural Studies 47, 220 (2016). 